\title{
Ketahanan Pangan Masyarakat Nelayan Pasca Bencana di Kota Palu
}

\author{
Asdi Tambur, Iwan Alim Saputra \\ Masuk: 17022021 / Diterima: 11092021 / Dipublikasi: 01122021
}

\begin{abstract}
This study aims to determine the food security condition of fishing communities in Palu City after the disaster, especially for fishing communities in Panau Village and Lere Village. The population in this study amounted to 357 fishing families with a total sample of 71 families. The sampling technique used is proportional random sampling. Data collection techniques were carried out using observation, documentation, and interview to analyze quantitative descriptive with a scoring method. The level of food security of the fishing community after the disaster in Panau Village is in a condition of food security with a percentage of $66.67 \%$, and less food security $33.33 \%$ in Lere Village. The level of resilience of the fishing community is in a food security condition with a percentage of $63.16 \%$ and less food security with a percentage of $36.84 \%$. Thus, it can be concluded that the post-disaster food security of fishing communities in Palu City is included in the category of food-secure households.
\end{abstract}

Key words: Food Security; Fishermen; Post Disaster

Abstrak Penelitian ini bertujuan untuk mengetahui kondisi ketahanan pangan masyarakat nelayan di Kota Palu pasca bencana di khusukan pada masyarakat nelayan di Kelurahan Panau dan Kelurahan Lere. Populasi dalam penelitian ini berjumlah 357 keluarga nelayan dengan jumlah sampel sebanyak 71 keluarga. Teknik pengambilan sampel yang digunakan adalah proporsional random sampling. teknik pengumpulan data dilakukan dengan teknik observasi, dokumentasi dan wawancara, untuk analisis data mengunakan deskriptif kuantitati dengan metode scoring. Tingkat ketahanan pangan masyarakat nelayan pasca bencana di Kelurahan Panau berada pada kondisi tahan pangan dengan persentase 66,67 \%, dan kurang tahan pangan $33,33 \%$ di Kelurahan Lere. Tingkat ketahanan masyarakat nelayan berada pada kondisi tahan pangan dengan persentase 63,16 \% dan kurang tahan pangan dengan persentase 36,84\%. Sehingga dapat disimpulkan ketahanan pangan masyarakat nelayan pasca bencana di Kota Palu termasuk dalam kategori rumah tangga tahan pangan.

Kata kunci: Ketahanan Pangan; Nelayan; Pasca Bencana

This is an open access article under the CC BY-SA license.

Copyright $\odot 2021$ by Author. Published by Universitas Pendidikan Ganesha.

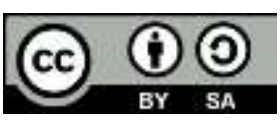

\section{Pendahuluan}

Bencana yang sering melanda Negara Indonesia adalah gempa bumi, hal ini diakibatkan Indonesia terletak dijalur pertemuan tiga lempeng tektonik dunia, yaitu lempeng eurasia yang bergerak relative kearah tenggara,

\footnotetext{
${ }^{1}$ Asdi Tambur, ${ }^{1}$ Iwan Alim Saputra

${ }^{1}$ Universitas Tadulako, Indonesia
}

asditambur28@gmail.com lempeng indo-australia yang bergerak relative kearah utara, dan lempeng pasifik yang relative bergerak kearah barat. Tabrakan antara lempenglempeng yang selalu bergerak itulah yang mengakibatkan terjadinya gempa bumi di Indonesia, gempa bumi yang disebabkan oleh tumbukan antara lempeng ini disebut gempa tektonik, akibat dari tumbukan lempeng tersebut 
terbentuk jalur penunjaman (zona subduksi) (Nurjanah, 2013).

Kota Palu merupakan salah satu kota yang berada di Indonesia yang rawan terhadapa bencana gempa bumi, hal ini dikarenakan dilalui oleh sesar aktif palu koro yang sering memicu terjadi gempa. Pada tanggal 28 September 2018 gempa kembali terjadi yang disusul dengan bencana tsunami dan likuifaksi yang memporaporandakan kota Palu dan sekitarnya. Berdasarkan data tahun 2020 yang diumumkan Badan Penangulangan Bencana Daerah Kota Palu korban bencana gempa bumi terdiri dari 3.679 orang, terbagi atas korban meninggal dunia berjumlah 2.132 jiwa, korban yang dikebumikan tidak teridentifikasi 1016 jiwa, dan korban hilang berjumlah 531 jiwa. Selain korban meninggal sekitar $6.596 \mathrm{KK}$ yang terdiri dari 24.517 jiwa kehilangan tempat tinggal.

Akibat dari bencana tersebut masyarakat nelayan yang paling merasakan dampak dari bencana tersebut, ini dikarenakan sebagian besar masyarakat nelayan bermukim di didaerah pesisir dan melakukan sebagian besar aktivitas di daerah pesisir. Data Dinas Pertanian dan Ketahanan Pangan Kota Palu (Bidang Perikanan) Tahun 2020, menjelaskan jumlah keluarga nelayan di Kota Palu 1066 KK yang tersebar di 17 Kelurahan di Kota Palu terdampak bencana. Kerugian akibat bencana yang dialami masyarakat nelayan diantaranya, kehilangan tempat tinggal, kehilangan harta benda, kehilangan perlengkapan melaut yaitu perahu dan alat tangkap ikan, dan lain, serta hal yang tidak diinginkan yaitu kehilangan keluarga.
Masyarakat nelayan akan dihadapkan pada pada berbagai permasalahan dalam kehidupan seharihari, mereka harus beradaptasi akan keadaan pasca bencana baik itu dari segi tempat tinggal atau lingkungan baru, serta psikologi yang harus menerima keluarga yang dicintai telah menjadi korban bencana, serta individu harus berjuang agar tetap sehat untuk serta mampu menjalani kehidupan bermasyarakat dengan baik, terutama dalam memenuhi kebutuhan pangan. Persediaan Pangan Kota Palu pada Tahun 2020 berdasarkan data dari Dinas Pertanian dan Ketahanan Pangan Kota Palu, mencukupi untuk kebutuhan masyarakat yang berjumlah 385.619 Jiwa.

Pangan cukup tersedia baik dari produksi maupun impor di skala regional ataupun wilayah, tidak menjamin semua individu dapat memenuhi kebutuhan pangannya sesuai standar kebutuhan minimum untuk hidup aktif karena keterbatasan akses, kemiskinan dan pengaruh variabel-variabel sosial ekonomi lainnya (Samad \& Wulandari, 2020). Kondisi inilah yang terjadi pada masyarakat nelayan pasca bencana di Kota Palu, walaupun ketersediaaan komoditas pangan strategis di Kota Palu cukup aman bagi masyarakat, namun tidak bagi masyarakat nelayan yang terdampak bencana dikarenakan keterbatasan akses pangan baik akses fisik maupun akses ekonomi.

Berbagai pihak telah meberikan bantuan kepada masyarakat nelayan untuk memulihkan kondisi perekonomiannya, baik pihak pemerintah, swasta, dan para relawan, terutama bantuan perahu dan alat 
penunjang melaut lainnya, dengan harapan kondisi perekonomian masyarakat nelayan di Kota Palu pasca bencana dapat pulih, sehingga masyarakat nelayan dapat memenuhi kebutuhan pangannya.

Aswantini (2004) menyatakan bahwa Pemenuhan kebutuhan (pangan) rumah tangga akan berpengaruh pada ketahanan pangan masyarakat secara umum, oleh karena itu betapa pentinggnya pengukuran ketahanan pangan masyarakat nelayan pasca bencana pada tingkat rumah tangga, sehingga diketahui tingkat ketahanan pangan masyarakat nelayan apakah berada pada tingkat tahan pangan, kurang tahan pangan, dan tidak tahan pangan. Ketahanan pangan masyarakat yang stabi, diharapkan mampu memberikan kesejahteraan masyarakat neayan yang terdampak bencana. Sehingga dapat dijadikan bahan evaluasi oleh pihak terkait untuk pengambilan kebijakan selanjutnya untuk mensejahterakan kehidupan nelayan di Kota Palu.

Dalam Undang-undang Nomor 18 Tahun 2012, dijelaskan mengenai ketahanan pangan adalah kondisi terpenuhinya pangan bagi Negara sampai dengan perseorangan yang tercermin dari tersediannya pangan yang cukup, baik jumlah maupun mutunya, aman, beragam, bergizi, merata, dan terjangkau serta tidak bertentangan dengan agama, keyakinan, dan budaya masyarakat, untuk dapat hidup sehat, aktif, dan produktif secara berkelanjutan. Pengukuran ketahanan pangan masyarakat nelayan pasca bencana $\mathrm{Di}$ Kota Palu diukur berdasarkan empat aspek ketahanan pangan yaitu: (1) kecukupan ketersediaan pangan, (2) stabilitas ketersediaan pangan, (3) akses atau keterjangkauan terhadap pangan, (4) kualitas serta keamanan pangan tersebut untuk dikomsumsi (Aswatini, 2004).

Pengukuran ketahanan pangan masyarakat nelayan pasca bencana Kot Palu dikhususkan pada masyarakat nelayan Kelurahan Lere dan Kelurahan Panau dengan mempertimbangkan di kedua kelurahan tersebut, merupakan wilayah yang paling terdampak bencana, serta didukung populasi masyarakat nelayan cukup besar dikedua kelurahan tersebut, sehingga pendekatan geografi yang digunakan dalam penelitian ini adalah pendekatan keruangan yang mengkaji fenomena fisik maupun sosial atau keterkaitan antara keduanya pada ruang yang menjadi lokasi penelitian. Metode yang digunakan adalah metode komparasi dengan cara membandingkan kondisi sosial ekonomi dan tingkat ketahanan pangan masyarakat nelayan pasca bencana di Kelurahan Panau dan Kelurahan Lere.

\section{Metode}

Jenis penelitian ini termasuk dalam penelitian deskiptif karena didalamnya terdapat gambaran tentang ketahanan pangan rumah tangga nelayan. Penelitian deskriptif ini bersifat deskriptif kuantitatif karena menggunakan statistik sederhana dalam menjelaskan ketahanan pangan rumah tangga nelayan pasca bencana di Kota Palu. Arikunto, Suharsimi, (2010) menytakan bahwa Penelitian 
deskriptif kuantitatif bertujuan untuk mengungkapkan kejadian atau fakta, keadaan, fenomena, dan keadaan yang terjadi saat penelitian berlangsung dengan menyuguhkan apa yang sebenarnya terjadi. Populasi dalam penelitian ini berjumlah 357 keluarga nelayan dengan jumlah sampel sebanyak 71 keluarga.

Teknik pengambilan sampel yang digunakan adalah proporsional random sampling. teknik pengumpulan data dilakukan dengan teknik observasi, dokumentasi dan wawancara Analisis data yang digunakan dalam melihat ketahanan pangan rumah tangga masyarakat nelayan terdampak bencana ini yakni analisis deskriptif kualitatif.

Secara administrasi lokasi dalam penelitian ini dilakukan di Kota Palu, namun penelitian ini mengunakan sampel wilayah yaitu Kelurahan Panau di Kecamatan Tawaeli dan Kelurahan Lere di Kecamatan Palu Barat, hal ini dikarenakan dikedua kelurahan tersebut populasi masyarakat nelayan yang besar dengan harapan dapat mewakili populasi masyarakat nelayan se-Kota Palu sehingga kedua kelurahan tersebut dipilih menjadi lokasi penelitian.

Kelurahan Panau merupakan salah satu kelurahan di Kecamatan Tawaeli, Kota Palu. Kelurahan Panau, berdasarkan data dari Badan Pusat Statistik Tahun 2018, mempunyai luas wilayah 2,08 $\mathrm{Km}^{2}$ dan jumlah penduduk sebanyak 4.014 Jiwa. Secara astronomis Kelurahan Lere terletak pada 0'5'13'41" LS dan 199 50'58,91" BT.

Administratif Kelurahan Lere: Sebelah Utara berbatasan dengan Teluk Palu, Sebelah Selatan berbatasan dengan Kelurahan Baru dan Kelurahan Siranindi, Sebelah Barat berbatasan dengan Kelurahan Silae dan Kelurahan Kabonena, dan sebelah timur berbatasan dengan Sungai Palu.Setiap tahunnya kepadatan penduduk Kelurahan Lere semakin meningkat karena disebabkan jumlah penduduknya semakin meningkat. Tahun 2018 dengan luas wilayah 2,97 $\mathrm{km}^{2}$, kepadatan penduduk tercatat sebanyak $3.991 \mathrm{jiwa} / \mathrm{km}^{2}$, artinya tiap km2 wilayahnya dihuni sebanyak 3.991 jiwa.

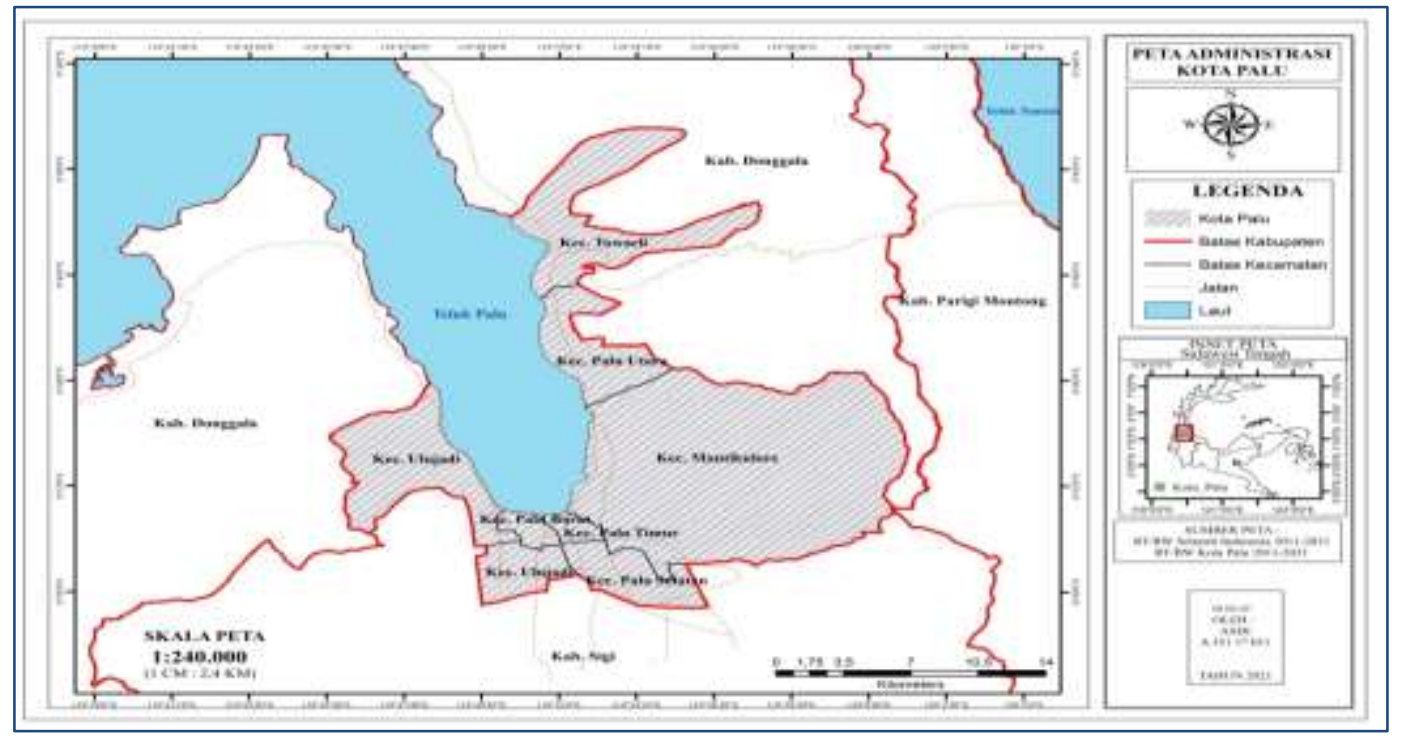

Gambar 1. Peta Lokasi Penelitian 


\section{Hasil dan Pembahasan}

Pengukuran ketahanan pangan yang dilakukan Tim Penelitian-LIPI tahun 2004 memperlihatkan terdapat empat komponen yang digunakan untuk mengukur ketahanan pangan di tingkat rumah tangga nelayan pasca bencana di Kota Palu. Keempat komponen tersebut yaitu, kecukupan ketersediaan pangan, stabilitas ketersediaan pangan, aksesibilitas/keterjangkauan pangan dan kualitas/keamanan pangan. Setiap indikator ketahanan pangan tersebut di analisis sehingga mendeskripsikan bagaimana keempat unsur tersebut membentuk ketahanan pangan rumah tangga nelayan di Kota Palu.

\section{Kecukupan Ketersediaan Pangan}

Menurut The Food and Agriculture Organization (FAO) 1996, Kecukupan dan ketersediaan ditingkat rumah tangga adalah suatu kondisi dimana setiap rumah tangga mempunyai ketersediaan pangan dalam jumlah yang cukup secara terus menerus tanpa ketidakpastian sehingga dapat memenuhi kebutuhan gizi yang diperlukan oleh seluruh anggota keluarga. Definisi tersebut mengandung dua maksud yaitu rumah tangga nelayan memeliki pangan yang cukup bagi anggota keluarga, dan tersedia bagi anggota keluarga setiap saat ketika bahan pangan tersebut dibutuhkan (Aswantini, 2004).
Tabel 1. Ketercukupan Ketersediaan

Pangan Masyarakat Nelayan

\begin{tabular}{|c|c|c|c|c|}
\hline \multirow[t]{3}{*}{ Kategori } & \multicolumn{4}{|c|}{ Kota Palu } \\
\hline & \multicolumn{2}{|c|}{$\begin{array}{l}\text { Kelurahan } \\
\text { Panau }\end{array}$} & \multicolumn{2}{|c|}{ Kelurahan Lere } \\
\hline & Jumlah & $(\%)$ & Jumlah & (\%) \\
\hline $\begin{array}{l}\text { Tidak } \\
\text { cukup }\end{array}$ & - & - & - & - \\
\hline $\begin{array}{l}\text { Kurang } \\
\text { cukup }\end{array}$ & - & - & - & - \\
\hline Cukup & 33 & $\begin{array}{c}100 \\
\%\end{array}$ & 38 & $\begin{array}{c}100 \\
\%\end{array}$ \\
\hline Jumlah & 33 & $100 \%$ & 38 & $100 \%$ \\
\hline
\end{tabular}

kecukupan ketersediaan pangan yang cukup, setiap beras yang dimasak disesuaikan dengan jumlah anggota keluarga, jika jumlah anggota keluarga dalam satu rumah tangga banyak maka beras yang dimasak juga semakin banyak. Untuk persediaan bahan makan dalam setiap bulannya masyarakat nelayan dikedua kelurahan tersebut memiliki stok yang cukup untuk kebutuhan pangan anggota keluarga.

\section{Stabilitas Ketersediaan Pangan}

berpendapat bahwa Stabilitas ketersediaan pangan dapat dilihat dari persediaan bahan pangan pokok dan frekuensi makan dalam suatu rumah tangga. Dalam suatu rumah tangga atau keluarga dikatakan stabil terhadap pangan jika memiliki pesediaan bahan pangan pokok (beras) dan makan tiga kali sehari seperti pada umumnya. Hal ini dapat dilihat pada Tabel 2. 
Tabel 2. Stabilitas Pangan

\begin{tabular}{|c|c|c|c|c|}
\hline \multirow[t]{3}{*}{ Kategori } & \multicolumn{4}{|c|}{ Kota Palu } \\
\hline & \multicolumn{2}{|c|}{$\begin{array}{l}\text { Kelurahan } \\
\text { Panau }\end{array}$} & \multicolumn{2}{|c|}{$\begin{array}{c}\text { Kelurahan } \\
\text { Lere }\end{array}$} \\
\hline & $\mathrm{N}$ & (\%) & $\mathrm{N}$ & (\%) \\
\hline $\begin{array}{l}\text { Tidak } \\
\text { Stabil }\end{array}$ & - & & 1 & $2,63 \%$ \\
\hline $\begin{array}{l}\text { Kurang } \\
\text { Stabil }\end{array}$ & 11 & $\begin{array}{c}33,33 \\
\%\end{array}$ & 12 & $\begin{array}{c}31,58 \\
\%\end{array}$ \\
\hline Stabil & 22 & $\begin{array}{c}66,67 \\
\%\end{array}$ & 25 & $\begin{array}{c}65,79 \\
\%\end{array}$ \\
\hline Jumlah & 33 & $100 \%$ & 38 & $100 \%$ \\
\hline
\end{tabular}

\section{Aksesibilitas Terhadap Pangan}

Akses pangan secara fisik ditunjukkan dengan kemampuan memproduksi pangan, kondisi infrastruktur dan sumber daya alam dan lingkungan pada wilayah tersebut. Seluruh rumah tangga nelayan tidak memiliki akses langsung terhadap bahan pangan pokok karena tidak memproduksi beras, akan tetapi memiliki akses langsung terhadap bahan pangan hewani berupa ikan segar karena melakukan kegiatan usaha ikan tangkap, sedangkan bahan pangan lainnya, diperoleh dengan cara membeli atau merupakan bahan pangan pemberian. Secara ekonomi, akses pangan dicerminkan dengan keterjangkauan harga pangan di wilayah tersebut, berdasarkan hasil pengamatan, bahan pangan selalu tersedia di pasar, toko, serta warung yang ada di lokasi penelitian dengan harga terjangkau (Defline Putri Delly, Fembriarti Erry Prasmatiwi, 2019).
Tabel 3. Aksesibilitas/keterjangkaun

Pangan Masyarakat Nelayan

\begin{tabular}{|c|c|c|c|c|}
\hline \multirow[t]{3}{*}{ Kategori } & \multicolumn{4}{|c|}{ Kota Palu } \\
\hline & \multicolumn{2}{|c|}{$\begin{array}{c}\text { Kelurahan } \\
\text { Panau }\end{array}$} & \multicolumn{2}{|c|}{$\begin{array}{l}\text { Kelurahan } \\
\text { Lere }\end{array}$} \\
\hline & $\mathrm{N}$ & $(\%)$ & $\mathrm{N}$ & $(\%)$ \\
\hline $\begin{array}{l}\text { Tidak } \\
\text { Terjangkau }\end{array}$ & - & - & - & - \\
\hline $\begin{array}{l}\text { Kurang } \\
\text { Terjangkau }\end{array}$ & 10 & $\begin{array}{c}30,30 \\
\%\end{array}$ & 7 & $\begin{array}{c}18,42 \\
\%\end{array}$ \\
\hline Terjangkau & 23 & $\begin{array}{c}69,70 \\
\%\end{array}$ & 31 & $\begin{array}{c}81,58 \\
\%\end{array}$ \\
\hline Jumlah & 33 & $100 \%$ & 38 & $100 \%$ \\
\hline
\end{tabular}

Secara keseluruhan masyarakat nelayan dalam mengakses pangan termasuk kategori terjangkau. Umumnya masyarakat nelayan di lokasi penelitian memperoleh bahan panagan dengan cara membeli dikarenakan tidak dapat memproduksi sendiri, adaun tempat mereka membeli di pasar ataupun di warung kecil/kios. Cara mereka mencapai tempat tersebut dengan cara yang beragam, mulai dari jalan kaki, naik sepeda motor, mengunakan jasa ojek, tergantung tempat mereka akan mendapatkan bahan pangan tersebut.

\section{Kualitas/keamanan Pangan}

Keamanan pangan dapat dilihat dari kualitas pangan yang memenuhi kebutuhan gizi. Penelitian ini ukuran keamanan pangan hanya dilihat dari ada atau tidaknya makanan yang dikonsumsi yang mengandung protein hewani dan nabati setiap harinya. 
Tabel 4. Kualitas/keamanan Pangan Masyarakat Nelayan

\begin{tabular}{|c|c|c|c|c|}
\hline \multirow[t]{3}{*}{ Kategori } & \multicolumn{4}{|c|}{ Kota Palu } \\
\hline & \multicolumn{2}{|c|}{$\begin{array}{l}\text { Kelurahan } \\
\text { Panau }\end{array}$} & \multicolumn{2}{|c|}{$\begin{array}{c}\text { Kelurahan } \\
\text { Lere }\end{array}$} \\
\hline & $\mathrm{N}$ & $(\%)$ & $\mathrm{N}$ & (\%) \\
\hline $\begin{array}{l}\text { Tidak ada } \\
\text { bahan } \\
\text { pangan } \\
\text { mengandung } \\
\text { protein } \\
\text { hewani dan } \\
\text { nabati }\end{array}$ & - & - & - & - \\
\hline $\begin{array}{l}\text { Ada bahan } \\
\text { pangan } \\
\text { mengandung } \\
\text { protein } \\
\text { hewani atau } \\
\text { nabati saja } \\
\text { (salah } \\
\text { satunya) }\end{array}$ & - & - & - & - \\
\hline $\begin{array}{l}\text { Ada bahan } \\
\text { pangan yang } \\
\text { mengandung } \\
\text { protein } \\
\text { hewani dan } \\
\text { nabati } \\
\text { (keduanya) }\end{array}$ & 33 & $100 \%$ & 38 & $\begin{array}{l}100 \\
\%\end{array}$ \\
\hline Jumlah & 33 & $100 \%$ & 38 & $100 \%$ \\
\hline
\end{tabular}

Masyarakat nelayan di Kelurahan Panau dan Kelurahan Lere, mengomsumsi pangan mengandung protein, baik itu protein hewani yaitu ikan, dan protein nabati yaitu sayuran. sehingga dikedua kelurahan tersebut memiliki kualitas atau keamanan pangan yang baik, protein yang ikan lebih tinggi dibandingkan daging sapi, ayam dan lain-lain, dikarenakan daging ikan memiliki serat-serat protein lebih pendek daripada serat-serat protein daging sapi atau ayam. Vitamin yang ada dalam ikan juga bermacam-macam yaitu vitamin A, D, Thiamin, Riboflavin, dan Niacin. Ikan juga mengandung mineral yang kurang lebih sama banyaknya dengan mineral yang ada dalam susu seperti kalsium, phosphor, akan lebih tinggi dibandingkan susu tergantung jenis ikannya.

Kondisi ketahanan pangan masyarakat nelayan pasca bencana di Kota Palu dapat diketahui melalui kuesioner yang disebarkan kepada 71 responden nelayam yang terdiri dari 33 nelayan di Kelurahan Panau dan 38 Kelurahan Lere, dengan pertanyaan mengenai empat indikator katahanan pangan yang dijabarkan diatas yaitu: kecukupan ketersediaan pangan, stabilitas ketersediaan pangan, akses terhadap pangan, dan kualitas pangan yang dikonsumsi. Dengan hasil tabulasi silang setiap indikator ketahanan pangan seperti terlihat pada Tabel 5 .

Tabel 5. Tingkat Ketahanan Pangan

\begin{tabular}{lcccc}
\multicolumn{5}{c}{ Masyarakat Nelayan } \\
\hline Kategori & \multicolumn{4}{c}{ Kota Palu } \\
\cline { 2 - 5 } & \multicolumn{2}{c}{$\begin{array}{c}\text { Kelurahan } \\
\text { Panau }\end{array}$} & \multicolumn{2}{c}{ Kelurahan } \\
& Lere & (\%) & N & $(\%)$ \\
\cline { 2 - 5 } & $\mathrm{N}$ & - & - & - \\
\hline Tidak & - & - & & \\
Tahan & & & & \\
Pangan & & & & 36, \\
\hline Kurang & 11 & 33,33 & 14 & $34 \%$ \\
Tahan & & $\%$ & & $84 \%$ \\
Pangan & & & & \\
\hline Tahan & 22 & 66,67 & 24 & 63,16 \\
Pangan & & $\%$ & & $\%$ \\
\hline Jumlah & 33 & $100 \%$ & 38 & $100 \%$
\end{tabular}

Sumber:Hasil Pengolahan Data Primer (2021)

Tabel 5 menunjukkan bahwa kondisi ketahanan pangan masyarakat nelayan pasca bencana di Kota Palu, di Kelurahan Panau berada pada kondisi tahan pangan dengan persentase $66,67 \%$, kurang tahan pangan dengan persentase $33,33 \%$ dan di Kelurahan 
Lere tahan pangan dengan persentase $63,16 \%$ dan kurang tahan pangan dengan persentase $36,84 \%$.

\section{Penutup}

Ketahanan pangan masyarakat nelayan di Kelurahan Panau berada pada kondisi tahan pangan yakni di Kelurahan Panau 66,67 \% dan di Kelurahan Lere yakni 63,16 \%. Diukur dengan mentabulasi silangkan empat indikator penunjang ketahanan pangan yaitu kecukupan ketersediaan pangan bagi keluarga nelayan, stabilitas ketersediaan pangan, aspek ketrejangkauan pangan bagi keluarga nelayan, dan terakhir adalah kualitas dan mutu pangan, didapatkan hasil tinkat ketahanan pangan masyarakat nelayan pasca bencana di Kota Palu berada pada tingkat baik.kekurangan dari penelitian ini adalah pengukuran tingkat ketahanan pangan masyarakat nelayan di Kota Palu tidak mengunakan analisis yang mendalam yang biasanya digunakan para peneliti dibidang pertanian, namun penelitian ini dapat dijadikan rujukan awal untuk penelitian selajutnya yang lebih mendalam pada bidang ketahanan pangan masyarakat nelayan di Kota palu, dikarenakan penelitian ini adalah penelitian perdana tentang ketahanan pangan masyarakat nelayan sebelum dan setelah bencana yang pernah dilakukan.

Kedepannya peneliti tentang ketahanan pangan masyarakat di kota Palu khususnya masyarakat nelayan perlu lebih ditingkatkan lagi terutama bagi peneliti yang lebih ahli dibidang ketahanan pangan, sehingga pemerintah dalam hal pemangku kebijakan mempunyai referensi yang lebih beragam untuk dijadikan pedoman untuk mesejahterakan masyarakat nelayan.

\section{Ucapan Terimakasih}

Penulis memberikan apresiasi kepada pihak yang terlah memberikan bantuan kepada peneliti sehingga dapat terselesaikan penelitian ini, Kepala Dinas Pertanian dan Ketahanan Pangan Kota Palu, Kepala Badan Penangulangan Bencana Dareh (BAPEDA) Kota Palu dan Kepala Badan Pusat Statistik Kota Palu, yang telah meberikan data yang diperlukan selama penelitian. Lurah, dan Pegawai Kelurahan serta masyarakat nelayan di Kelurahan Panau dan Kelurahan Lere yang telah berlapang dada meberikan izin serta membantu peneliti dalam mengambil data untul menyelesaikan penelitian ini, serta segala pihak yang tidak dapat penulis sebutkan satu persatu yang telah berkontribusi dalam membantu peneliti menyelesaikan penelitian ini, penulis mengucapkan terima kasih sebesar-besarnya, semoga penelitian ini bermanfaat bagi masyarakat secara umum dan dapat dijadikan rujukan bagi penelitian selanjutnya khususnya dibidang ketahanan pangan masyarakat.

\section{Daftar Pustaka}

Arikunto, S. (2010). Prosedur Penelitian Suatu Pendekatan Praktik. Jakarta: Rineka Cipta.

Aswantini, D. (2004). Ketahanan Pangan, Kemiskinan dan Sosial Demografi Rumah Tangga. Jakarta: Dikon Arto Sejahtera.
BPS Kabupaten Palu. (2019). Kecamatan Tawaeli Dalam Angka 2019.


BPS Kabupaten Palu. (2019). Palu

Barat Dalam Angka 2019.

Hidayati, C. S. (2006). Bahan Tambahan Pangan. Jakarta: Kanisius.

Iwan, A. S., \& Giyarsih, S. R. (2014). Studi komparatif Tranformasi Wilayah Di Kabupaten Klaten.

Mulyana, A. (2012). Penguatan Ketahanan Pangan untuk Menekan Jumlah Penduduk Miskin dan Rentan Pangan di Tingkat Nasional dan Regional. E-Journal Ekonomi Pertanian. 1(1).

Nurjanah. (2013). Manajemen Bencana. Yogyakarta: Alfabeta.

Prasmatiwi, F. E., Prayitno, R. T., \& Delly, D. P. (2019). Tingkat Ketahanan Pangan Rumah Tangga Nelayan Di Desa Sukajaya Lempasing Kecamatan Teluk Pandan Kabupaten Pesawaran. Jurnal IImu-IImu Agribisnis, 7(2), 141-148.

Saliem, H. P. (2002). Ketahanan pangan: konsep, pengukuran dan strategi. Jurnal Ilmiah Widya, 20(1), 12-24.

Samad, M. A., \& Wulandari, R. (2020). Evaluasi Kebijakan Pemerintah Pasca Bencana (Studi Kasus Bencana di Sulawesi Tengah). Jurnal IImu Administrasi, 9(1), 1524.

Saputra, I. A. (2019). Keterkaitan Faktor Sosial Ekonomi Rumah. Jurpis: Jurnal Pendidikan IImu Sosial. 16(2), 185-207.

Yunus, H. S. (2010). Metodologi Penelitian Wilayah Kontemporer Yoyakarta: Pustaka Pelajar. 